Kinga Szymańska

Sąd Metropolitalny Warszawski

ORCID 0000-0001-9000-3448

\title{
Parafilia wyzwaniem dla małżeństwa kanonicznego
}

Treść: Wstęp. 1. Klasyfikacje parafilii. 2. Kryteria diagnostyczne. 2.1. Kryteria diagnostyczne występujące w ICD. 2.2. Kryteria diagnostyczne występujące w DSM. 3. Etiopatogeneza. 4. Parafilie a małżeństwo kanoniczne. Zakończenie.

\section{Wstęp}

Podejmując określony w tytule problem badawczy należy zauważyć, że jak dotąd niewiele publikacji poświęcono tematyce parafilii w ogólności. Dyskusje na temat wpływu tego zaburzenia na małżeństwo kanoniczne jak dotąd były podejmowane w publikacjach głównie w rozważaniach nad homoseksualizmem oraz pedofilią. Taki stan stał się bodźcem do podjęcia tematyki ujętej w tytule tego opracowania.

\section{Klasyfikacje parafilii}

Jak zauważa Zbigniew Lew-Starowicz, nie ma jednej i oficjalnej klasyfikacji parafilii ${ }^{1}$. W podobny sposób wypowiada się profesor medycyny sądowej i toksykologii z University of Delhi Anil Aggrawal, konstatując, iż co prawda z biomedycznego punktu widzenia parafilie zostały wyraźnie zdefiniowane w DSM, ale ich lista obejmuje jedynie

1 Por. Z. Lew-Starowicz, Seksuologia sądowa, Warszawa 2000, s. 104. 
15 przypadków choć, na co zwraca się uwagę w DSM, ich katalog jest otwarty ${ }^{2}$.

Należy zauważyć, iż w tym zakresie klinicyści posiłkują się systematyzacjami wypracowanymi przez niektóre autorytety $\mathrm{w}$ dziedzinie psychiatrii i seksuologii. Jedną z pierwszych opracował w 1976 roku Dawid Sadoff ${ }^{3}$. Omawiając ją Anil Aggrawal zauważył, iż Sadoff, podzielił parafilie na dwie grupy: „dewiacje agresywne” (,aggressive” deviations), jak np. gwałt, pedofilia, sadomasochizm oraz „anonimowe dewiacje” („anonymous” deviations), przykładem czego może być voyeuryzm bądź telefoniczna skatofilia ${ }^{4}$ Pomiędzy tymi dwoma grupami, kontynuuje profesor z University of Delhi, Sadoff wskazał na kilka parafilii, w których sprawca zachowuje zmienny stopień anonimowości wobec ofiary (victim). Jego zdaniem największa anonimowość pojawia się $\mathrm{w}$ fetyszyzmie, gdyż z reguły sprawca nie ma kontaktu z ofiarą. Następnie wymienił nieprzyzwoite rozmowy telefoniczne, podglądactwo, ekshibicjonizm oraz frotteuryzm; ostatnią

2 Por. A. Aggrawal, Paraphilias and Sexual Crimes-An Overview, w: A. Jamieson, A. Moenssens (red.), Wiley Encyclopedia of Forensic Science (Five Volume Set), edycja online z 2016 r., s. 2, http://onlinelibrary.wiley.com/doi/10.1002/9780470061589. fsa1023/pdf (dostęp: 12.01.2020): „From a biomedical point of view, paraphilias have been defined explicitly in the Diagnostic and Statistical Manual, 4th edition, revised (DSM-IV-TR). It specifically mentions 15 paraphilias by name. Of these, eight have been allotted specific diagnostic codes (Table 1). Seven other paraphilias - telephone scatologia (obscene phone calls), necrophilia (sexual attraction to corpses), partialism (exclusive focus on part of body), zoophilia (sexual attraction to animals), coprophilia (erotic attraction to feces), klismaphilia (enemas), and urophilia (urine) - are grouped in the category "paraphilia not otherwise specified» [diagnostic code 302.9]. It is specifically mentioned that «examples include, but are not limited to» these representative examples."

3 Por. D.H. Sadoff, Other sexual deviations, w: B.J. SAdock, H.I. Kaplan, A.M. Freedman (red.), The Sexual Experience, Baltimore 1976.

4 Por. A. Aggrawal, Forensic and Medico-legal Aspects of Sexual Crimes and Unusual Sexual Practices, New York 2008, s. 14: „In one of the earliest classifications, Sadoff [16] divided all paraphilias in two broad groups - «aggressive» deviations, such as rape, pedophilia, and sadomasochism, and «anonymous» deviations, such as voyeurism and telephone scatologia." 
wymienioną postacią był gwałt charakteryzujący się jawnym i siłowym kontaktem fizycznym $\mathrm{z}$ ofiarą ${ }^{5}$.

Według Sadoff'a anonimowe dewiacje pozwalają sprawcy uchronić się przed lękiem, którego może doświadczyć, gdy dochodzi do bezpośredniej konfrontacji lub kontaktu z pożądanym obiektem fantazji seksualnych. W jego opinii, ci anonimowi zboczeńcy seksualni (anonymous sex deviates) mogą fantazjować o stosunku seksualnym, ale $\mathrm{z}$ reguły są zbyt niespokojni, aby fantazje te wcielić w czyn ${ }^{6}$.

Odnosząc się krytycznie do tej typologii, Aggrawal zauważa, że Sadoff w swych rozważaniach nie wziął pod uwagę faktu, iż ekshibicjonizm nie jest w sensie ścisłym, jak to określił, „anonimowym” odchyleniem, gdyż ofiara widzi oraz rozpoznaje sprawcę

Drugą klasyfikacją, na którą zwrócił uwagę Aggrawal, jest systematyzacja opracowana w 1984 roku przez Dawida L. Rosenhana i Martina E.P. Seligmana ${ }^{8}$. Wspominani naukowcy wyróżnili trzy kategorie parafilii. Pierwszą stanowią parafilie, związane z podnieceniem seksualnym oraz preferencją dotyczącą niedobrowolnych partnerów (nonconsenting partners), przykładem czego są ekshibicjonizm, podglądactwo oraz molestowanie dzieci; w drugiej z kolei kategorii

5 Por. TAмżE: „In between these two poles lie several paraphilias where the offender maintains variable degree of anonymity with the victim. The sequence from greatest anonymity to least may be something like this: fetishism (absolutely no contact with the victim) $\rightarrow$ obscene telephone calling (verbal contact only) $\rightarrow$ voyeurism (goes physically near to the victim, but is hidden from victim's view) $\rightarrow$ exhibitionism (comes in full view of the victim, but no physical contact) $\rightarrow$ frotteurism (goes on to establish physical contact with the victim, but in a crowd, thus maintaining his anonymity) $\rightarrow$ rape (frank, overt, forceful physical contact). Exhibitionism is not exactly an "anonymous" deviation, as the victim does get to see (and recognize) the offender, but Sadoff remains silent on this issue."

6 Por. TAmżE: „He, however, suggests that anonymous deviations do help the offender to save himself from the anxiety which he may experience when he comes in direct confrontation or contact with the desired sexual object. In Sadoff's view, these anonymous sex deviates may fantasize having sexual intercourse but are too anxious about it to be able to really go through the process of accomplishing it."

7 Por. TAMżE.

8 Por. D.L. Rosenhan, M.E. P. Seligman, Abnormal Psychology, New York 1984. 
kluczową rolę odgrywa podniecenie seksualne i preferowanie obiektów nieosobowych, co może mieć miejsce w fetyszyzmie oraz transwestytyzmie; wreszcie wyszczególniono kategorię charakteryzującą się tym, że zamiast obiektu ludzkiego lub przedmiotu innego niż człowiek, preferuje się określone sytuacje związane z cierpieniem i upokarzaniem. Postaci, o których mowa mogą wystąpić w sadyzmie, masochizmie czy piromanii ${ }^{9}$.

Lew-Starowicz utrzymuje, że wraz z rozwojem psychiatrii lista parafilii ulega wydłużeniu ${ }^{10}$. W tym kontekście seksuolog ten podał opracowaną w 1986 roku typologię, autorstwa Johna Money’a (1921-2006), traktującego parafilie jako „złożone relacje między miłością, zmysłowością, miłością, romantyzmem i śmiercią"11. W oparciu o tak określone założenie Money wyróżnił sześć typów dewiacji: ofiarno-pokutny (autoassassinofilia); łupieżczo-drapieżczy (raptofilia); merkantylno-korupcyjny (chrematisofilia) oraz fetyszystyczno-talizmanny (fetysze) ${ }^{12}$.

Sam Lew-Starowicz w „Seksuologii sądowowej” podał ponad 70 przykładów parafilii, zaznaczając jednocześnie, iż w literaturze naukowej opisano ich już ponad $200^{13}$.

Konkludując ten passus należy zauważyć, iż występująca w publikacjach precyzyjnie nieokreślona liczba parafilii świadczy o coraz

9 Por. A. Aggrawal, Forensic and Medico-legal Aspects of Sexual Crimes and Unusual Sexual Practices, .... „Rosenhan and Seligman divide paraphilias into three categories.The first is where there is sexual arousal and preference for nonconsenting partners. This category includes paraphilias such as exhibitionism, voyeurism, and child molestation. In the second category, there is sexual arousal and preference for nonhuman objects. These paraphilias include fetishism and transvestism. Finally, there is a category where, instead of a human or nonhuman object, the preference is for certain situations. In sadism and masochism, for example, the preference is for situations that involve suffering and humiliation; in pyromania, for situations that include fire; and so on."; M.E. P. Seligman, E.F. Walker, D.L. Rosenhan, Psychopatologia, Poznań 2003, s. 585.

10 Por. Z. Lew-Starowicz, Seksuologia..., dz. cyt., s. 104.

11 Por. TAmże.

12 Por. TAMżE.

13 Por. TAmże, s. 105-106. 
większym zróżnicowaniu w obszarze ludzkich preferencji seksualnych, których przedmiotem może być nie tylko osoba, ale i przedmiot bądź czynność.

\section{Kryteria diagnostyczne}

Interesującą nas kategorię zaburzeń, jaką są parafilie, uwzględniono zarówno w DSM-5, jak i w ICD-10. Poruszając ten problem, na wstępie należy stwierdzić, iż wydania ICD poprzedzające ICD-6 zawierały wyłącznie klasyfikację śmiertelności (pierwsza wersja nosiła nazwę „Międzynarodowa lista przyczyn zgonu” [The International List of Causes of Death]). Dopiero w zatwierdzonym w 1948 roku ICD-6 przez nowo utworzoną Światową Organizację Zdrowia do podręcznika włączono klasyfikację zachorowalności, w tym również zaburzeń psychicznych. W Rozdziale ICD-6 dotyczącym zaburzeń psychicznych, psychoneurotycznych i osobowości (Mental, Psychoneurotic, and Personality Disorders) znalazła się kategoria „Dewiacje seksualne” (Sexual Deviation), do których zaliczano: ekshibicjonizm, fetyszyzm, patologiczną seksualność (pathologic sexuality) oraz sadyzm ${ }^{14}$.

W zatwierdzonym w 1955 roku ICD-7 ta sekcja pozostała niezmieniona. Znaczne zmiany w tym zakresie zapoczątkowano wraz z publikacją w 1965 roku ICD-8. W ramach „Dewiacji seksualnych” ujęte bowiem zostały takie kategorie jak: homoseksualizm, fetyszyzm, pedofilia, transwestytyzm, ekshibicjonizm oraz inne dewiacje seksualne (Other Sexual Deviation). W ramach tej ostatniej kategorii ulokowano: masochizm, narcyzm, nekrofilię, sadyzm oraz podglądactwo ${ }^{15}$.

W opublikowanym w 1975 roku ICD-9 w strukturze Rozdziału „Zaburzenia psychiczne” (Mental Disorders) umieszczono podrozdział „Zaburzenia seksualne i dewiacje” (Sexual Disorders and

14 Por. R.B. Krueger, G.M. Reed, M.B. First, A. Marais, E. Kismodi, P. Briken, Proposals for Paraphilic Disorders in the International Classification of Diseases and Related Health Problems, Eleventh Revision (ICD-11), Archives of Sexual Behavior 46(2017) nr 5, s. 1531.

15 Por. TAmżE. 
Deviation), wskazując na: homoseksualizm, zoofilię, pedofilię, transwestytyzm, ekshibicjonizm, transseksualizm, zaburzenia tożsamości psychoseksualnej (Disorders of Psychosexual Identity), oziębłość (Frigidity), impotencję oraz inne dewiacje lub zaburzenia seksualne (Other Sexual Deviation or Disorder). Do ostatniej kategorii włączono: fetyszyzm, masochizm i sadyzm. Komentując tę zmianę, autorzy artykułu „Proposals for Paraphilic Disorders in the International Classification of Diseases and Related Health Problems, Eleventh Revision (ICD-11)" konstatują, że po raz pierwszy w ICD zdefiniowano każde zaburzenie wymienione w rozdziale „Zaburzenia psychiczne”. Po czym dopowiedzieli, iż do tej pory nie tylko nie definiowano, ale i nie podawano wytycznych do diagnozy żadnej z chorób występujących w ICD ${ }^{16}$. Kolejne zmiany przyniosła dziesiąta odsłona ICD, o czym szczegółowo będzie mowa w następnym punkcie opracowania.

W odniesieniu do amerykańskiej klasyfikacji oraz faktu uznania parafilii za jednostkę chorobową należy zauważyć, iż przed publikacją DSM-I w 1952 roku nietypowe zainteresowania seksualne klasyfikowano jako przypadki osobowości psychopatycznej z patologiczną seksualnością ${ }^{17}$.

W pierwszej edycji DSM z kolei parafilie określono w ramach kategorii „dewiacje seksualne” (sexual deviation 000-x63), definiując je jako odchylenia seksualne. W ujęciu tym jedno kryterium wyartykułowano następująco: „diagnoza ta powinna być zarezerwowana dla dewiacyjnej seksualności, która nie jest objawem bardziej rozległych zespołów, takich jak schizofrenia i reakcja obsesyjna"18. Jednocześnie wymieniono takie rodzaje patologicznych zachowań

\footnotetext{
16 Por. TAMżE.

17 Por. A.R. Beech, M.H. Miner, D. Thornton, Paraphilias in the DSM-5, Annual Review of Clinical Psychology 12(2016) nr 1, s. 384-385.

18 Por. Diagnostic and Statistical Manual Mental Disorders, Washington DC 1952, s. 38: "This diagnosis is reserved for deviant sexuality which is not symptomatic of more extensive syndromes, such as schizophrenic and obsessional reactions."
} 
jak: homoseksualizm, transwestytyzm, pedofilia, fetyszyzm i sadyzm seksualny (w tym gwałt, napaść na tle seksualnym i okaleczenie) ${ }^{19}$.

W drugiej edycji DSM z 1968 roku nadal posługiwano się terminem „dewiacja seksualna” (sexual deviation 302), wyjaśniając jednocześnie, iż kategoria ta „jest przeznaczona dla osób, których zainteresowania seksualne są skierowane przede wszystkim na przedmioty, na czynności seksualne niezwiązane ze stosunkiem płciowym lub na kopulację podejmowaną w dziwnych okolicznościach, takich jak nekrofilia, pedofilia, seksualny sadyzm i fetyszyzm"20. Ponadto dotychczasowy katalog patologicznych zachowań rozszerzono o: ekshibicjonizm, (Exhibitionism 302.4), oglądactwo (Voyeurism 302.5), masochizm (Masochism 302.7), inne seksualne dewiacje (Other sexual deviation 302.8) oraz nieokreślone dewiacje seksualne (Unspecified sexual deviation 302.9$)^{21}$.

Omawiając zmiany występujące w DSM-III ${ }^{22}$ autorzy artykułu "Paraphilias in the DSM-5” konstatują, że parafilie zostały wprowadzone jako podzbiór kategorii zaburzeń psychoseksualnych, szeroko definiowanych jako nawracające, intensywnie pobudzające seksualnie fantazje, popędy seksualne lub zachowania obejmujące przedmioty nieludzkie, cierpienie lub upokorzenie siebie bądź partnera,

19 Por. TAмżE, s. 39: „The term includes most of the cases formerly classed as "psychopathic personality with pathologic sexuality». The diagnosis will specify the type of the pathologic behavior, such as homosexuality, transvestism, pedophilia,fetishism and sexual sadism (including rape, sexual assault, mutilation)". 20 Por. Diagnostic and Statistical Manual of Mental Disorders, Washington DC 1968, s. 44: „This category is for individuals whose sexual interests are directed primarily toward objects other than people of the opposite sex, toward sexual acts not usually associated with coitus, or toward coitus performed under bizarre circumstances as in necrophilia, pedophilia, sexual sadism, and fetishism. Even though many find their practices distasteful, they remain unable to substitute normal sexual behawior for them. This diagnosis is not appropriate for individuals who perform deviant sexual acts because normal sexual objects are not available to them".

21 Por. TAmżE.

22 Por. Diagnostic and Statistical Manual of Mental Disorders (DSM-III), Washington DC 1980. 
dzieci lub osób nie wyrażających zgody ${ }^{23}$. W opublikowanej w 1987 roku rewizji omawianego podręcznika (DSM-III-R) wprowadzono kryterium czasu trwania zaburzenia, które winno trwać dłużej niż sześć miesięcy ${ }^{24}$. Wyjaśniając umiejscowienie parafilii w zaburzeniach seksualnych i tożsamości płciowej, wspominani naukowcy stwierdzają, że sugerowało to, iż etiologia i progresja parafilii miały wiele wspólnego z innymi dysfunkcjami seksualnymi, takimi jak np. zaburzenia erekcji, pochwica, przedwczesny wytrysk, hipoaktywne pożądanie seksualne. Poza tym, kontynuują, ta definicja umieściła parafilie w sferze zaburzeń seksualnych i pozwoliła klinicystom badać je jako odchylenia od tego, co jest ogólnie uważane za normalne zachowanie seksualne ${ }^{25}$.

Należy dodać, iż w opublikowanej w 1994 roku czwartej edycji DSM pozostawiono bez zmian zakres podmiotowy parafilii oraz kryterium czasowe; utrzymano również definicje parafilii opracowane w DSM III i DSM-III-R ${ }^{26}$.

Kolejną zmianę przyniosła rewizja czwartej odsłony podręcznika Amerykańskiego Towarzystwa Psychiatrycznego (DSM-IV-TR ${ }^{27}$ ). W pozycji tej bowiem wprowadzono dwa kryteria definiujące parafilię. W kryterium A określono ją jako powtarzające się, intensywne, podniecające seksualnie fantazje, popędy seksualne lub zachowania, występujące przez okres co najmniej sześciu miesięcy, zakresowo obejmujące: (a) przedmioty inne niż ludzkie; (b) cierpienie lub upokorzenie siebie albo partnera, lub (c) dzieci bądź innych osób, które nie wyrażają na to zgody. W kryterium B z kolei wprowadzano warunek, iż parafilia łącznie z kryterium A klinicznie winna powodować

\footnotetext{
23 Por. A.R. Beech, M.H. Miner, D. Thornton, Paraphilias in the DSM-5..., dz. cyt., s. 386-389.

24 Por. TAMżE.

25 Por. TAMżE.

26 Por. J.M. W. Bradford, A.G. Ahmed, The natural history of paraphilia, Psychiatric Clinics of North America 37(2014) nr 2, s. xiii.

27 Por. Diagnostic and Statistical Manual of Mental Disorders. Text Revision (DSMIV-TR), Washington DC 2000.
} 
poważny stres bądź upośledzenie w życiu społecznym, zawodowym lub w innych ważnych obszarach ludzkiego funkcjonowania ${ }^{28}$.

\subsection{Kryteria diagnostyczne występujące w ICD}

W ICD-10 parafilie umiejscowiono w Rozdziale V zatytułowanym „Zaburzenia osobowości i zachowania dorosłych” (Disorders of adult personality and behaviour) (F60-69); bardziej konkretnie w podrozdziale "Zaburzenia preferencji seksualnych” (Disorders of sexual preference) $(\mathrm{F} 65)^{29}$. Systematyzacyjnie podzielono je na zaburzenia specyficzne oraz niespecyficzne. W ramach pierwszej kategorii wymieniono osiem zaburzeń: „Fetyszyzm” (Fetishism, F65.0) "Transwestytyzm fetyszystyczny” (Fetishistic transvestism F65.1), „Ekshibicjonizm” (Exhibitionism F65.2), „Oglądactwo” (Voyeurism F65.3), „Pedofilia” (Paedophilia F65.4), „Sadomasochizm” (Sadomasochism F65.5) oraz „Złożone zaburzenia preferencji seksualnych” (Multiple disorders of sexual preference F65.6). Oprócz powyższych do omawianej kategorii jeszcze zaliczono: „Inne zaburzenia preferencji seksualnych" (Other disorders of sexual preference F65.8), wskazując na: prowadzenie obscenicznych rozmów telefonicznych, ocieranie się o ludzi w zatłoczonych miejscach publicznych, kontakty seksualne ze zwierzętami bądź też wykorzystanie podduszania lub niedotlenienia w celu zintensyfikowania doznań seksualnych, a także „Froteryzm” (Frotteurism) i „Nekrofilię” (Necrophilia) ${ }^{30}$.

Natomiast do zaburzeń niespecyficznych zaliczono „Zaburzenia preferencji seksualnych nieokreślone” (dewiacje seksualne bliżej nieokreślone) (Disorder of sexual preference, unspecified Sexual deviation

\footnotetext{
28 Por. A.R. Beech, M.H. Miner, D. Thornton, Paraphilias in the DSM-5..., dz. cyt., s. 387-388.

29 Por. International Statistical Classification of Diseases and Related Health Problems 10th Revision (ICD-10), t. 1, Geneva 2016, s. 322-329.

30 Por. TAmże, s. 328-329.
} 
NO F65.9) nie podając żadnych konkretnych jednostek, tym samym $\mathrm{w}$ tym zakresie pozostawiono swobodę w diagnozowaniu ${ }^{31}$.

Jak zauważają: Stanisław Pużyński i Jerzy Wciórka w ICD-10 określono trzy kryteria generalne dotyczące diagnozy zaburzeń preferencji seksualnych ${ }^{32}$. Zarówno wspominani klinicyści, jak i Lidia Cierpiałkowska ${ }^{33}$, wskazują na: po pierwsze, konieczność doświadczania nasilonego popędu i wyobrażeń seksualnych dotyczących niezwykłych przedmiotów i działań; po drugie, realizując ten popęd dana osoba odczuwa wyraźne cierpienie, co jednak nie powstrzymuje ją od tego typu aktywności; po trzecie, wskazana preferencja musi trwać przez okres przynajmniej 6 miesięcy.

18 czerwca 2018 roku Światowa Organizacja Zdrowia opublikowała na swojej stronie internetowej nową wersję klasyfikacji, jaką jest ICD-11. Dokument zawierający ponad 50 tysięcy kodów urazów, chorób i przyczyn śmierci ma zacząć obowiązywać od 2022 roku $^{34}$.

$\mathrm{Z}$ analizy rozwiązań systematyzacyjnych tej pozycji wynika, że zaburzenia parafiliczne (paraphilic disorders, 6D30-6D3Z) zostały umieszczone w Rozdziale VI „Zaburzenia psychiczne, behawioralne lub neurorozwojowe” (Mental, behavioural or neurodevelopmental disorders). W ramach tej kategorii wyróżniono: „ekshibicjonizm” (Exhibitionistic disorder 6D30), „oglądactwo” (Voyeuristic disorder 6D31), „pedofilię” (Pedophilic disorder 6D32), „przymusowy sadyzm seksualny” (Coercive sexual sadism disorder 6D33) oraz „ocieractwo” (Frotteuristic disorder 6D34) ${ }^{35}$. Dodatkowo wprowadzono kategorię: „inna parafilia z udziałem osoby niewyrażającej zgody” (Other paraphilic disorder involving non-consenting individuals 6D35).

\footnotetext{
31 Por. TAMżE.

32 Por. S. Pużyński, J. WCióRKa (red.), Klasyfikacje zaburzeń psychicznych i zaburzeń zachowania w ICD-10. Badawcze kryteria diagnostyczne, Kraków 1998, s. 124-125.

33 Por. L. CierpiaŁkowska, Psychopatologia, Warszawa 2014, s. 331.

34 Por. International Statistical Classification of Diseases and Related Health Problems 11th Revision (ICD-11), w: https://icd.who.int/browsel1/l-m/en\#/http://id.who. int/icd/entity/2110604642 (Dostęp: 15.12.2019).

35 Por. TAMżE.
} 
Jednocześnie wyjaśniono, iż chodzi o parafilię charakteryzującą się trwałym i intensywnym wzorcem nietypowego podniecenia seksualnego przejawiającego się w postaci myśli, fantazji, popędów lub zachowań seksualnych. Zgodnie z wyjaśnieniami zawartymi w ICD-11, wzorzec pobudzenia koncentruje się na innych, którzy nie chcą lub nie mogą wyrazić zgody ${ }^{36}$. Jednocześnie w jedenastej rewizji ICD zastrzeżono, że do tego zaburzenia nie są zaliczane zachowania seksualne, które mają miejsce za zgodą osoby lub osób zaangażowanych, pod warunkiem, że uznaje się je za zdolne do wyrażenia takiego przyzwolenia $^{37}$. Z kolei kategorię „parafilia dotycząca własnych zachowań lub zachowań z udziałem osoby wyrażającej zgodę" (Paraphilic disorder involving solitary behaviour or consenting individuals 6D36) zdefiniowano jako zaburzenie parafiliczne zakresowo obejmujące zachowanie danej osoby lub osoby wyrażającej zgodę, które charakteryzuje się trwałym i intensywnym wzorcem nietypowego podniecenia seksualnego przejawiającego się w postaci myśli, fantazji, popędów bądź zachowań. Poza tym w tym wypadku warunkiem koniecznym jest wymóg, aby dana czynność seksualna odbywała się za zgodą drugiej

36 Por. TAMżE: „Other paraphilic disorder involving non-consenting individuals is characterised by a persistent and intense pattern of atypical sexual arousal - manifested by sexual thoughts, fantasies, urges, or behaviours - in which the focus of the arousal pattern involves others who are unwilling or unable to consent but that is not specifically described in any of the other named Paraphilic Disorders categories (e.g., arousal patterns involving corpses or animals). The individual must have acted on these thoughts, fantasies or urges or be markedly distressed by them". 37 Por. TAMżE: „Other paraphilic disorder involving non-consenting individuals is characterised by a persistent and intense pattern of atypical sexual arousal - manifested by sexual thoughts, fantasies, urges, or behaviours - in which the focus of the arousal pattern involves others who are unwilling or unable to consent but that is not specifically described in any of the other named Paraphilic Disorders categories (e.g., arousal patterns involving corpses or animals). The individual must have acted on these thoughts, fantasies or urges or be markedly distressed by them. The disorder specifically excludes sexual behaviours that occur with the consent of the person or persons involved, provided that they are considered able to provide such consent". 
osoby $^{38}$. Dodatkowo musi występować jeden z następujących dwóch faktorów: po pierwsze, osoba winna być wyraźnie zestresowana naturą wzorca pobudzenia; doznane cierpienie natomiast nie jest po prostu konsekwencją odrzucenia lub strachu przed odrzuceniem wzorca pobudzenia przez innych; po drugie, charakter zachowania parafilicznego wiąże się ze znacznym ryzykiem urazu lub śmierci jednostki bądź jej partnera (np. asfiksjofilia) ${ }^{39}$.

Ostatnią kategorią wyróżnioną w ICD-11 jest „zaburzenia parafiliczne niespecyficzne" (Paraphilic disorders, unspecified 6D3Z) określone mianem „niespecyficzne” kategorie rezydualne ${ }^{40}$. Jak zauważają: Piotr Krawczyk i Łukasz Święcicki, w jedenastej odsłonie podręcznika WHO usunięto z omawianego podrozdziału „fetyszyzm”, „transwestytyzm fetyszystyczny” oraz „sadomasochizm”. Co więcej, z dwuczęściowej kategorii sadomasochizmu usunięto całkowicie masochizm, a zaburzenie opisywane jako „sadyzm seksualny" ma w swej nazwie i definicji warunek stosowania przymusu wobec drugiej osoby ${ }^{41}$.

Należy też zauważyć, iż w ICD-11 przy każdej z wyodrębnionych kategorii zaburzeń parafilicznych podano ogólne kryteria

38 Por. TAмżE: „Paraphilic disorder involving solitary behaviour or consenting individuals is characterised by a persistent and intense pattern of atypical sexual arousal - manifested by sexual thoughts, fantasies, urges, or behaviours - that involves consenting adults or solitary behaviours."

39 Por. TAмżE: „Paraphilic disorder involving solitary behaviour or consenting individuals is characterised by a persistent and intense pattern of atypical sexual arousal - manifested by sexual thoughts, fantasies, urges, or behaviours - that involves consenting adults or solitary behaviours. One of the following two elements must be present: 1) the person is markedly distressed by the nature of the arousal pattern and the distress is not simply a consequence of rejection or feared rejection of the arousal pattern by others; or 2) the nature of the paraphilic behaviour involves significant risk of injury or death either to the individual or to the partner (e.g., asphyxophilia).”

40 Por. TAмżE: „This category is an «unspecified» residual category”.

41 Por. P. KrawCZy K, Ł. ŚWIĘCICKI, ICD-11 vs. ICD-10 - przegląd aktualizacji i nowości wprowadzonych w najnowszej wersji Międzynarodowej Klasyfikacji Chorób WHO, Psychiatria Polska 54(2020) nr 1, s. 18. 
klasyfikacyjne. Zamieszczono również definicję zaburzenia parafilicznego, zgodnie z którą zaburzenia te „charakteryzują się trwałymi i intensywnymi wzorcami nietypowego podniecenia seksualnego, przejawiającego się myślami, fantazjami, popędami lub zachowaniami seksualnymi, które koncentrują się na innych, których wiek lub stan sprawia, że nie chcą lub nie są w stanie wyrazić zgody i na które dana osoba działała lub przez które jest wyraźnie zestresowana. Zaburzenia parafilne mogą obejmować wzorce pobudzenia obejmujące zachowania danej osoby lub osoby wyrażającej zgodę tylko wtedy, gdy są one związane z wyraźnym cierpieniem, które nie jest po prostu wynikiem odrzucenia lub obawy odrzucenia wzorca pobudzenia przez innych lub ze znacznym ryzykiem obrażeń lub śmierci" ${ }^{42}$.

Wspomniani autorzy artykułu „Proposals for Paraphilic Disorders in the International Classification of Diseases and Related Health Problems, Eleventh Revision (ICD-11)” pozytywnie odnieśli się do pozostawienia zaburzeń parafilnych w Rozdziale „Zaburzenia osobowości i zachowania dorosłych”. Ich zdaniem spełniają one ogólne wymagania dotyczące diagnozy zaburzeń psychicznych. W ich przekonaniu kolokacja parafilii, a także postrzeganie jej w kategoriach zaburzenia psychicznego jest istotna z punktu widzenia medycyny sądowej, kryminalistyki oraz opiniowania przez biegłych sądowych ${ }^{43}$.

\footnotetext{
42 Por. International Statistical Classification of Diseases and Related Health Problems 11th Revision...: „Paraphilic disorders are characterised by persistent and intense patterns of atypical sexual arousal, manifested by sexual thoughts, fantasies, urges, or behaviours, the focus of which involves others whose age or status renders them unwilling or unable to consent and on which the person has acted or by which he or she is markedly distressed. Paraphilic disorders may include arousal patterns involving solitary behaviours or consenting individuals only when these are associated with marked distress that is not simply a result of rejection or feared rejection of the arousal pattern by others or with significant risk of injury or death". 43 Por. R.B. Krueger, G.M. Reed, M.B. First, A. Marais, E. Kismodi, P. Briken, Proposals for Paraphilic Disorders..., dz. cyt., s. 1541.
} 


\subsection{Kryteria diagnostyczne występujące w DSM}

Podobnie jak w ICD-10, tak i w DSM-5 wyróżniono trzy kategorie zaburzeń parafilcznych. Pierwsza $z$ nich to zaburzenia specyficzne zakresowo obejmujące osiem głównych jednostek chorobowych, tj. „Zaburzenie voyeurystyczne” (Voyeuristic Disorder 302.82), „zaburzenie ekshibicjonistyczne” (Exhibitionistic Disorder 302.4), „zaburzenie frotteurystyczne” (Frotteuristic Disorder 302.89), „zaburzenie masochistyczne” (Sexual Masochism Disorder 302.83), „zaburzenie sadystyczne” (Sexual Sadism Disorder 302.84), „zaburzenie pedofilne” (Pedophilic Disorder 302.2), "zaburzenie fetyszystyczne” (Fetishistic Disorder 302.81) oraz „zaburzenie transwestytyczne” (Transvestic Disorder 302.3) ${ }^{44}$. Ponadto wyróżniono dwie dodatkowe kategorie: „Inne określone zaburzenia parafiliczne” (Other Specified Paraphilic Disorder, 302.89), przykładem czego są: zoofilia, urofilia, telefoniczna skatofilia, nekrofilia, koprofilia ${ }^{45}$ oraz „nieokreślone zaburzenia parafiliczne" (Unspecified Paraphilic Disorder 302.9) charakteryzujące się tym, że powodują poważne kliniczne cierpienie, ale nie spełniają kryteriów któregokolwiek z zaburzeń specyficznych ${ }^{46}$. W tym

44 Por. Diagnostic and Statistical Manual of Mental Disorders (DSM-5), Washington DC - London 2013, s. 686-704.

45 Por. TAmżE, s. 705: „This is done by recording «other specified paraphilic disorder» followed by the specific reason (e.g. «zoophilia»). Examples of presentations that can be specified using the «other specified» designation include, but are not limited to, recurrent and intense sexual arousal involving telephone scatologia (obscene phone calls), necrophilia (corpses), zoophilia (animals), coprophilia (feces), klismaphilia (enemas), or urophilia (urine) that has been present for at least 6 months and causes marked distress or impairment in social, occupational, or other important areas of functioning. Other specified paraphilic disorder can be specified as in remission and/or as occurring in a controlled environment”.

46 Por. TAMżE, s. 705: „This category applies to presentations in which symptoms characteristic of a paraphilic disorder that cause clinically significant distress or impairment in social, occupational, or other important areas of functioning predominate but do not meet the full criteria for any of the disorders in the paraphilic disorders diagnostic class. The unspecified paraphilic disorder category is used in situations in which the clinician chooses not to specify the reason that the criteria 
kontekście należy zauważyć, iż w DSM-5 podtrzymano podział na dwie jednostki diagnostyczne: parafilię (paraphlia) oraz zaburzenia parafiliczne (paraphilic disorders) ${ }^{47}$. Pierwszą z nich określono jako „wszelkie przypadki silnego i trwałego zainteresowania seksualnego innego niż stymulacja genitalna czy pieszczoty wstępne $\mathrm{z}$ fenotypowo normalnym, fizycznie dojrzałym i dającym przyzwolenie ludzkim partnerem” ${ }^{48}$. Tym samym, jak konstatują autorzy artykułu „Kryteria zaburzeń parafilnych w DSM-5 wobec asfiksji autoerotycznej i pozaseksualnej formy ograniczania dopływu tlenu" parafilia to atypowa seksualna preferencja, która nie stanowi zaburzenia i nie wymaga leczenia, jeśli nie powoduje cierpienia, stresu, krzywdy (lub ryzyka jej wyrządzenia), czyli sytuacji w której nie zostało spełnione kryterium $\mathrm{B}^{49}$. Podobnego zdania są Adam Mic i Zbigniew Lew-Starowicz, zdaniem których parafilia sama w sobie nie może być uznawana ani za chorobę ani za zaburzenie, co odróżnia DSM-5 od ICD-10 ${ }^{50}$.

Inaczej sytuacja wygląda w przypadku „zaburzenia parafilnego”, które zostało zdefiniowane jako „parafilia, która powoduje wyraźne cierpienie psychiczne i zaburzenie funkcjonowania społecznego u danej osoby bądź też krzywdę i cierpienie lub ryzyko ich wystąpienia u osób trzecich”51. Według autorów artykułu „Zaburzenia parafilne w ujęciu DSM-5” sama parafilia (kryterium A) jest warunkiem ko-

are not met for a specific paraphilic disorder, and includes presentations in which there is insufficient information to make a more specific diagnosis".

47 Por. TAMżE, s. 685.

48 Por. TAMżE: „The term paraphilia denotes any intense and persistent sexual interest other than sexual interest in genital stimulation or preparatory fondling with phenotypically normal, physically mature, consenting human partners".

49 Por. M. Dora, M. Mijas, B. Dobroczyński, Kryteria zaburzeń parafilnych w DSM-5 wobec asfiksji autoerotycznej i pozaseksualnej formy ograniczania dopływu tlenu, Psychiatria Polska 53(2019) nr 5, s. 1104.

50 Por. A. Mic, Z. LEw-Starowicz, Zaburzenia parafilne w ujęciu DSM-5, Przegląd Seksuologiczny 10(2014) z. 2, s. 16.

51 Por. Diagnostic and Statistical Manual of Mental Disorders (DSM-5)..., dz. cyt., s. 685-686: „A paraphilic disorder is a paraphilia that is currently causing distress or impairment to the individual or a paraphilia whose satisfaction has entailed personal harm, or risk of harm, to others. A paraphilia is a necessary but not 
niecznym, ale niewystarczającym do zdiagnozowania omawianego zaburzenia $^{52}$. Zgodnie bowiem z wymogami określonymi przez Amerykańskie Towarzystwo Psychiatryczne, oprócz wspominanego kryterium A, które ma charakter jakościowy, wymaga się również, aby wystąpiło kryterium B określające negatywne konsekwencje danego zaburzenia parafilnego przejawiającego się np. w cierpieniu, krzywdzie, czy też w zaburzeniach psychospołecznych ${ }^{53}$.

Krytycznie do takiego podziału odniosły się Marta Dora, Magdalena Mijas oraz Bartłomiej Dobroczyński, uznając to za dążenie do „depatologizacji alternatywnych fantazji, pragnień i zachowań seksualnych"54. Odmienne stanowisko prezentują wspominani już: Mic i Lew-Starowicz, stwierdzając, iż podział na parafilie i zaburzenia parafilne istnieje już od czasów DSM-III-R (1987 rok), i w tym zakresie DSM-5 nie wnosi nic nowego ${ }^{55}$. Poza tym, konstatują wspominani seksuolodzy, uznanie parafilii per se za atypowe zachowania seksualne, które jednak nie stanowią jednostki chorobowej, wynika z praktyki klinicznej, gdzie przeważnie do leczenia trafiają osoby odczuwające cierpienie lub wywołujące takie cierpienie u partnera; $\mathrm{z}$ tego powodu podlegają odpowiedzialności karnej ${ }^{56}$.

a sufficient condition for having a paraphilic disorder, and a paraphilia by itself does not necessarily justify or require clinical intervention".

52 Por. A. Mic, Z. Lew-Starowicz, Zaburzenia parafilne..., dz. cyt., s. 16.

53 Por. Diagnostic and Statistical Manual of Mental Disorders (DSM-5)..., s. 686: „A paraphilia is a necessary but not a sufficient condition for having a paraphilic disorder, and a paraphilia by itself does not necessarily justify or require clinical intervention. In the diagnostic criteria set for each of the listed paraphilic disorders. Criterion A specifies the qualitative nature of the paraphilia (e.g., an erotic focus on children or on exposing the genitals to strangers), and Criterion B specifies the negative consequences of the paraphilia (i.e., distress, impairment, or harm to others). In keeping with the distinction between paraphilias and paraphilic disorders, the term diagnosis should be reserved for individuals who meet both Criteria A and B (i.e., individuals who have a paraphilic disorder)".

54 Por. M. Dora, M. Mijas, B. Dobroczyński, Kryteria zaburzeń parafilnych w DSM-5..., dz. cyt., s. 1104.

55 Por. A. Mic, Z. Lew-Starowicz, Zaburzenia parafilne..., dz. cyt., s. 16.

56 Por. TAMŻE, s. 24. 
Warto zauważyć, iż w DSM-5 zwrócono m.in. uwagę na współwystępowanie zaburzeń voyeurystycznych, ekshibicjonistycznych łącznie $\mathrm{z}$ frotteurystyzmem ${ }^{57}$, masochizmu seksualnego $\mathrm{z}$ fetyszyzmem transwestycyjnym ${ }^{58}$, sadyzmu seksualnego $\mathrm{z}$ innymi parafiliami ${ }^{59}$; pedofilii i innych parafilii ${ }^{60}$ oraz zaburzeń fetyszystycznych łącznie z hiperseksualnością ${ }^{61}$.

Komentując zmiany wprowadzone w piątej edycji podręcznika Amerykańskiego Towarzystwa Psychiatrycznego, Anthony R. Beech, Michael H. Miner oraz David Thornton zauważają, że DSM-5 jest pierwszą wersją, w której rozróżnia się parafilie, będące anomalnymi preferencjami docelowymi (anomalous target preferences) oraz parafilie będące anomalnymi preferencjami seksualnymi (anomalous sexual preferences). Ostatnie $\mathrm{z}$ wymienionych podzielono jeszcze na dwie podgrupy: zaburzenia zalotów (courtship disorders), będące teoretycznym konstruktem w seksuologii, w którym pewne parafilie są postrzegane jako specyficzne przykłady anomalnych zachowań zalotowych, szczególnie u mężczyzn; drugą grupę natomiast stanowią zaburzenia algolagiczne (algolagnic disorders), w których podniecenie seksualne jest zależne od bólu i cierpienia ${ }^{62}$.

W tym miejscu należy zwrócić uwagę, że ci sami naukowcy krytykują jednak pewne rozwiązania dotyczące aktualnej typologii parafilii występującej w nowej edycji DSM ${ }^{63}$. Nawiązując do pracy „Problems with paraphilias in the DSM-5" ${ }^{\prime 4}$, stwierdzają, że w omawianej klasyfikacji zawarto jedynie negatywną definicję parafilii. Po drugie, ich

57 Por. Diagnostic and Statistical Manual of Mental Disorders (DSM-5)..., dz. cyt., s. 693.

58 Por. TAMżE, s. 695

59 Por. TAMżE, s. 697.

60 Por. TAmże, s. 700.

61 Por. TAmże, s. 703

62 Por. A.R. Beech, M.H. Miner, D. Thornton, Paraphilias in the DSM-5..., dz. cyt., s. 388-390.

63 Por. TAMżE, s. 383-406.

64 Por. J.P. Fedoroff, L. Di Gioncchino, L. Murphy, Problems with paraphilias in the DSM-5, Current Psychiatry Report 15(2013) s. 1-6. 
zdaniem, problematyczna jest również kwestia rozpowszechnienia parafilii bowiem wskaźniki wahają się między $2 \%$ a $30 \%$. Po trzecie, nie uznano za stosowne, aby w diagnozie zaburzeń parafilnych uwzględnić czynniki kulturowe. Po czwarte, zignorowano czynniki etiologiczne poszczególnych zaburzeń parafilicznych. I po piąte, nie ma przeprowadzonych odpowiednich badań terenowych pozwalających klinicystom na rozróżnienie w diagnozie zaburzenia parafilnego od innych zaburzeń ${ }^{65}$.

Podsumowując ten passus należy zauważyć, że problemów w diagnozowaniu nastręcza odmienność definiowania parafilii w ICD-10 (zaburzenie psychiczne) oraz w DSM-5 (podział na niebędące jednostkami chorobowymi parafilie i będące zaburzeniami „zaburzenia parafilne”). Tym samym w klasyfikacji Amerykańskiego Towarzystwa Psychiatrycznego zauważalna jest tendencja do niepatologizowania niektórych parafilii. Rozróżnienie to jest istotne z punktu widzenia psychiatrów czy biegłych sądowych, bowiem to, którą klasyfikację wybierze klinicysta, będzie istotne nie tylko w aspekcie klinicznym, ale i sądowo-seksuologicznym. Z drugiej strony warte wspomnienia są wyjaśnienia autorów artykułu „Proposals for Paraphilic Disorders in the International Classification of Diseases and Related Health Problems, Eleventh Revision (ICD-11)”, zdaniem których różnice między obiema klasyfikacjami są czymś naturalnym, bowiem obie organizacje stojące za ich opracowaniem mają odmienne cele oraz pełnią odmienną rolę ${ }^{66}$.

\section{Etiopatogeneza}

Z pierwszych badań prowadzonych przez Johna Money i Kenta W. Simcoe wynikało, że przyczyny parafilii mogą tkwić zarówno w początkowej fazie rozwoju dziecka, jak i w późnym niemowlęctwie

\footnotetext{
65 Por. A.R. Beech, M.H. Miner, D. Thornton, Paraphilias in the DSM-5..., dz. cyt., s. 383-384.

66 Por. R.B. Krueger, G.M. Reed, M.B. First, A. Marais, E. Kismodi, P. Briken, Proposals for Paraphilic Disorders..., dz. cyt., s. 1541.
} 
czy też we wczesnym dzieciństwie; mogą się też pojawić się przed rozpoczęciem pokwitania jako skutek zahamowania i wypaczenia normoficznego rozwoju ${ }^{67}$.

Mimo upływu prawie trzydziestu lat od wyartykułowania powyższych tez, okazuje się, iż etiologia parafilii nadal pozostaje nieznana ${ }^{68}$. Co więcej, Norbert Konrad, Justus Welke oraz Anette Optiz-Welke wskazują, że dotąd nie ma naukowego wyjaśnienia poglądu, iż parafilie występują znacznie częściej u mężczyzn niż u kobiet; nie ma też jednoznacznych ustaleń odnośnie, najlepszego podejścia terapeutycznego w leczeniu zaburzenia parafilnego ${ }^{69}$.

Jeśli chodzi o demografię osób, u których zdiagnozowano parafilię, to interesujące w tym zakresie są rezultaty badań autorstwa Michaela W. Wiedermana ${ }^{70}$. Stwierdził on, iż parafilia występuje bez względu na rasę czy przynależność do określonej grupy społeczno-ekonomicznej. Jego zdaniem zachowania, a przynajmniej zainteresowanie parafilne pojawiają się na dość wczesnym etapie rozwoju, czasem w dzieciństwie, a także w okresie dojrzewania. W tym ostatnim przypadku, jak i we wczesnej dorosłości natura parafilicznych fantazji i zachowań zwykle staje się bardziej skomplikowana, bowiem osoba doświadcza więcej niż jednej formy parafilii ${ }^{71}$.

Autorzy artykułu „Paraphilias in the DSM-5” starając się wyjaśnić występowanie tylu niewiadomych w przypadku diagnozowania

67 Por. J. Money, K.W. Simcoe, Acrotomophilia, Sex and Disability: New Concepts and Case Report, Sexuality and Disability 7(1984) nr 1-2, s. 49: „The foregoing information is consistent with what one learns from individual patients in the clinic. Thus it may be accepted as phenomenologically authentic. Etiologically, there is still no completely adequate explanation of the genesis of acrotomophilia in particular, nor of paraphilias in general. The available evidence points to a developmental onset in late infancy or early childhood, tong before the onset of puberty, probably as a response to the thwarting and warping of normophilic development".

${ }^{68}$ Por. N. Konrad, J. Welke, A. Optiz-Welke, Paraphilias, Current Opinion in Psychiatry 28(2015) nr 6, s. 440.

69 Por. TAMżE.

70 Por. M.W. Wiederman, Paraphilia and fetishism, The Family Journal 11(2003) nr 3, s. 315-321.

71 Por. TAмżE, s. 316. 
parafilii zauważają, że większość parafilii to karalne przestępstwa seksualne (np. podglądactwo, ekshibicjonizm, ocieractwo i pedofilia); natomiast kryminogenność innych może być uzależniona od kwestii występowania lub nie zgody danej osoby (np. masochizm, sadyzm). Jeszcze inne parafilie (np. transwestytyzm, fetyszyzm) nie podlegają karalności ale mogą być postrzegane przez określone grupy społeczne za moralnie i społecznie naganne ${ }^{72}$.

Z powyższych względów, gdy prowadzono badania, to zazwyczaj obejmowały one diagnozę przestępców seksualnych, w której to grupie dominowali mężczyźni. Przykładem może być badanie przeprowadzone na grupie 113 osadzonych przestępców, którego wyniki opublikowano w artykule „Psychiatric and legal features of 113 men convicted of sexual offenses"73. Mianowicie stwierdzono występowanie parafilii u 74\% badanych. Ponadto wykazano współwystępowanie parafilii z zaburzeniami nastroju (presence of any mood disorder), depresją (major depression), chorobą afektywną dwubiegunową typu I (bipolar I disorder), wszelkimi zaburzeniami lękowymi (any anxiety disorder), zaburzeniami kontroli impulsów (any impulse control disorder) oraz zaburzeniami wynikającymi z osobowości unikającej

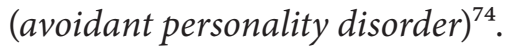

Co interesujące, osoby z parafilią zgłaszały więcej osób, które były ich ofiarami, zaczęły popełniać przestępstwa w młodszym wieku; częściej dopuszczały się kazirodztwa niż osoby, u których nie zdiagnozowano parafilii. Dodatkowo osoby z parafilią były również bardziej skłonne do skazania lub przyznania się do rażącego seksualnego wykorzystywania nieletniego ${ }^{75}$.

72 Por. A.R. Beech, M.H. Miner, D. Thornton, Paraphilias in the DSM-5..., dz. cyt., s. 385-387.

73 Por. N.W. Dunsieth, E.B. Nelson, L. A Brusman-Lovins, J.L. Holcomb, D. Beckman, J.A. Welge, D. Roby, P. Taylor Jr, C.A. Soutullo, S.L. McElroy, Psychiatric and legal features of 113 men convicted of sexual offenses, Journal of Clinical Psychiatry 65(2004) nr 3, s. 293-300.

74 Por. TAmże, s. 293.

75 Por. TAMżE: „Although Ss without paraphilias spent more time in prison than those with paraphilias, paraphilic Ss reported more victims, started offending at 
W innych badaniach opublikowanych w dwóch artykułach naukowych: „The nature and extent of sexual assault” ${ }^{\prime 6}$ oraz „Sexual history disclosure using the polygraph in a sample of British sex offenders in treatment"77 spostrzeżono, że osoby przejawiające jedną parafilię uznaną za patologiczną bardzo często wykazują objawy innych parafilii (np. pedofilia, oglądactwo, ekshibicjonizm, ocieractwo).

Wspominany już Lew-Starowicz omawiając zagadnienie czynników mających wpływ na powstanie parafilii dokonuje ich podziału na dwie kategorie. W pierwszej kolejności wymienia czynniki biologiczne jak: zaburzenia genetyczne (np. zespół Klinefeltera), zaburzenia neurologiczne (np. padaczka skroniowa, encefalopatia, stwardnienie rozsiane, choroba Parkinsona, wodogłowie, nowotwory mózgu). Polski seksuolog do tej kategorii zaliczył również uzależnienia (od alkoholu, narkotyków), choroby psychiczne (np. afektywne). Autor ten wskazał także na predyspozycje genetyczne oraz czynniki hormonalne $\mathrm{e}^{78}$.

W drugiej kolejności stwierdził, że źródłem parafilii mogą być czynniki psychiczne, jak i uwarunkowania powstałe w wyniku fantazji erotycznych czy oglądania pornografii. W tej części wywodu Lew-Starowicz wskazał również na zaburzenia identyfikacji

a younger age, and were more likely to perpetrate incest. Paraphilic Ss were also more likely to be convicted of or admit to gross sexual imposition of a minor".

76 Por. G. Abel, J. Rouleau, The nature and extent of sexual assault, w: W.L. MARSHALL, D.R. LAws, H.E. BArbaree (red.), Handbook of Sexual Assault: Issues, Theories and Treatment of the Offender, New York 1990, s. 16: „The results presented in Table 2 demonstrate that, irrespective of the category of specific paraphilia, members in any one specific category were concurrently involved, or had been involved, in other specific categories of paraphilic behavior. These data contradict the conventional literature that paraphiliacs have one and only one specific category of deviant sexual behavior. These results reflect quite the opposite finding; that individuals with one and only one paraphilia are rather uncommon, and that the majority of paraphiliacs have or have had multiple, specific categories of paraphilic interest". 77 Por. D. Wilcox, D. Sosnoski, B. Warberg, A.R. Beech, Sexual history disclosure using the polygraph in a sample of British sex offenders in treatment, Polygraph Journal 34 (2005) nr 3, s. 171-181.

78 Por. Z. Lew-Starowicz, Seksuologia..., dz. cyt., s. 103. 
seksualnej, urazy, szoki i wykorzystywanie seksualne w dzieciństwie czy kompleks niższości z potrzebą dominacji. Ponadto parafilie, jego zdaniem, mogą powodować zaburzenia osobowości typu osobowość wielokrotna czy osobowość borderline ${ }^{79}$.

W poszukiwaniu etiopatogenezy parafilii powołał się też się na opisany w publikacji „A general psychiatric approach to sexual deviation" ${ }^{80}$ integracyjny model seksualnej dewiacyjności, w którym wyróżniono dwie kategorie czynników dewiacji: pierwszą stanowiły czynniki wewnętrzne takie jak: doświadczenia nabyte w wieku dziecięcym, fantazje, zaburzenia psychiczne oraz osobowości, guzy i urazy mózgu, jak również opóźniony rozwój umysłowy oraz zaburzenia hormonalne; drugą kategorią były czynniki zewnętrzne, do których zaliczono: doświadczenie przemocy, wykorzystywanie seksualne, problemy interpersonalne oraz interspychiczne, wpływ alkoholu, a także nieudane związki uczuciowe ${ }^{81}$.

Według Wiedermana funkcjonujące w psychologii teorie biologiczne, psychoanalityczne czy poznawczo-behawioralne mają charakter spekulatywny, dlatego jego zdaniem istnieje paląca potrzeba dodatkowych opracowań i danych empirycznych, aby jednoznacznie określić etologię omawianego zjawiska ${ }^{82}$.

\section{Parafilie a małżeństwo kanoniczne}

Przeprowadzone analizy wskazują na to, iż parafilia jest nie tylko zjawiskiem złożonym, ale przede wszystkim niedostatecznie zbadanym. Jak dotąd do końca nie rozstrzygnięta pozostaje kwestia etiopatogenezy parafilii. Nieliczne badania kliniczne, co prawda wskazują na pewne czynniki mające wpływ na zachowania dewiacyjne, to jednak nie są one miarodajne, gdyż w większości przypadków badania były

\footnotetext{
79 Por. TAMżE.

80 Por. B. Brockman, R. Bluglass, A general psychiatric approach to sexual deviation w: I. Rosen (red.), Sexual deviation, Oxford-New York-Tokyo 1996, s. 1-42.

81 Por. Z. Lew-StarowiCz, Seksuologia..., dz. cyt., s. 103-104.

82 Por. M.W. Wiederman, Paraphilia and fetishism..., dz. cyt., s. 318-320.
} 
prowadzone w grupach osób skazanych za przestępstwa seksualne. Należy założyć, że grupa ta stanowi niewielki odsetek populacji, trudno więc uznać ją za reprezentatywną. Argument ten popiera Lew-Starowicz konstatując, że właśnie w tej nieujawnionej części populacji znajduje się odpowiedź na nurtujące klinicystów pytanie o mechanizm powstawania parafilii ${ }^{83}$.

Parafilie, zwane w przeszłości dewiacjami lub perwersjami, mogą mieć wpływ na małżeństwo i rodzinę o czym świadczy fakt, iż problamatyka zaburzeń psychoseksualnych coraz częściej staje się przedmiotem analiz w sądach kościelnych w kontekście prowadzenia procesów o stwierdzenie nieważności małżeństwa. Współmałżonkowie zazwyczaj zarzucają parafilikom zaniedbywanie podstawowych obowiązków małżeńskich, czy też wykluczanie podstawowych przymiotów małżeństwa. Stąd też sprawy mogą być prowadzone z niezdolności konsensualnej (kan. 1095 KPK), symulacji (kan. 1101 KPK), podstępu (kan. 1098 KPK), a także w specyficznych kazusach z błędu co do przymiotu wprost i zasadniczo zamierzonego (kan. $1097 \$ 2 \mathrm{KPK})$.

\section{Zakończenie}

Poczynione w niniejszym artykule rozważania uprawniają do stwierdzenia, że parafilik z reguły postrzega związek małżeński z egoistycznego pryzmatu, gdyż wszystko, co robi, ma na celu zaspokojenie jego przyjemności. Nie liczy się z drugą osobą, nie wykluczając możliwości traktowania jej w sposób przedmiotowy, instrumentalny. Innymi słowy, parafilik traktuje partnera jak rzecz, po to, aby zaspokoić samolubną potrzebę rozkoszy seksualnych. Tymczasem w związku małżeńskim poszukuje się bliskości i realizacji dobra względem współmałżonka będącego równorzędnym partnerem. Parafilizm natomiast będący impulsem seksualnym niszczy nie tylko małżeństwo, ale i współmałżonka; w mniejszym czy większym stopniu również osobę dotkniętą tym zaburzeniem. Poza tym w związku

83 Por. Z. Lew-Starowicz, Seksuologia..., dz. cyt., s. 108. 
z parafilikiem nie ma stabilności, nie dochodzi do realizacji dobra małżonka, ani też do realizacji małżeńskiej wspólnoty życia i miłości; dominuje zaś nienaturalna instynktowna seksualna satysfakcja ${ }^{84}$. Takie związki mogą trafić na wokandę sądów kościelnych, wówczas $\mathrm{w}$ prowadzeniu takich spraw należy skorzystać z opinii biegłych. Prafilia bowiem sama w sobie nie powoduje nieważności małżeństwa. W ocenie stanu faktycznego niezwykle istotny jest stopień jej nasilenia, dlatego też odrębnie trzeba rozpatrzyć każdą wniesioną sprawę.

\section{Paraphilia as a challenge for canonical marriage}

\section{Summary}

The considerations made in this article justify the conclusion that a paraphilic assesses the marriage from a selfish perspective, because everything he does is aimed at satisfying his pleasure. He does not consider the other person or the possibility of treating him objectively - in other words, a parafilik treats his partner as a thing to satisfy his selfish need for pleasure. Meanwhile, in the marriage relationship, closeness and realization of the good of the other party are sought as an equal partner. On the other hand, paraphilism, which is a sexual impulse, destroys not only the marriage but the spouse and, to a greater or lesser extent, the paraphilic himself. In a marriage with a paraphilic, there is no stability, no realization of the spouse's good, no realization of the community of life and love, only instinctive satisfaction, which is also unnatural. Nevertheless, regardless of the definition of paraphilia in medical sciences and psychology, when conducting a trial in an ecclesiastical court, it should be verified in the light of the concept of Christian anthropology, proper to canon studies. The paraphilia itself does not nullity it, it all depends on the severity of the disorder in question and its impact on the functioning in marriage.

${ }^{84}$ Por. J.A. Fuentes, Desviaciones de la sexualidad. Parafilias y transsexualismo en las causas de nulidad matrimonial canonica, Ius Canonicum 53(2013) $\mathrm{nr}$ 106, s. 663-664. 
Słowa kluczowe: parafilia, zaburzenie parafilne, kanoniczne prawo małżeńskie, nieważność małżeństwa, proces małżeński

Key words: paraphilia, paraphilic disorders, canonical marriage law, marriage nullity, marriage proces

\section{Nota o autorze}

Dr Kinga Szymańska - doktor nauk prawnych w zakresie prawa kanonicznego, prawnik, politolog religii. Notariusz i audytor w Sądzie Metropolitalnym Warszawskim. Autorka publikacji z zakresu małżeńskiego prawa kanonicznego, psychiatrii i psychologii. 